\title{
Glass fragment embedded in the cheek: a missed radiographic finding
}

\section{Balasubramanian Madhan, Gnanasekaran Arunprasad, Balasubramanian Krishnan}

Department of Dentistry, Jawaharlal Institute of Postgraduate Medical Education and Research, Puducherry, India

\section{Correspondence to}

Dr Balasubramanian Madhan, madhanb@hotmail.com

Accepted 24 November 2015

\section{CrossMark}

To cite: Madhan $B$, Arunprasad G, Krishnan B. BMJ Case Rep Published online: [please include Day Month Year] doi:10.1136/ bcr-2015-210542

\section{DESCRIPTION}

A 20-year-old man reported to the outpatient clinic, with concerns regarding a $10 \times 13 \mathrm{~mm}$ glass fragment that had allegedly expulsed from his right cheek wound 10 days prior (figure 1). His medical records revealed that he had sustained a road traffic accident (RTA) and had been operated for fractures of the mandible 3 weeks earlier. He was unable to recollect the exact nature of the facial injury, allegedly due to a short spell of unconsciousness following the incident.

Clinical examination revealed a $12 \mathrm{~mm}$ scar in the cheek near the right ear lobule, reminiscent of a healed laceration wound (figure 1). No tenderness or discharge was noted. There were no other relevant extraoral or intraoral findings. Close scrutiny of the presurgical dental panoramic radiograph revealed radio-opacity in the right mid-ramus region, matching the outline of the glass fragment (figure 2).

Corroborating the above findings, it was speculated that the glass piece had lodged in the subcutaneous plane of the right cheek during the injury and had then uneventfully expulsed during wound healing due to proximity to the surface. Irrespective of whether the radiographic finding was missed or ignored, it reminds us of two facts.

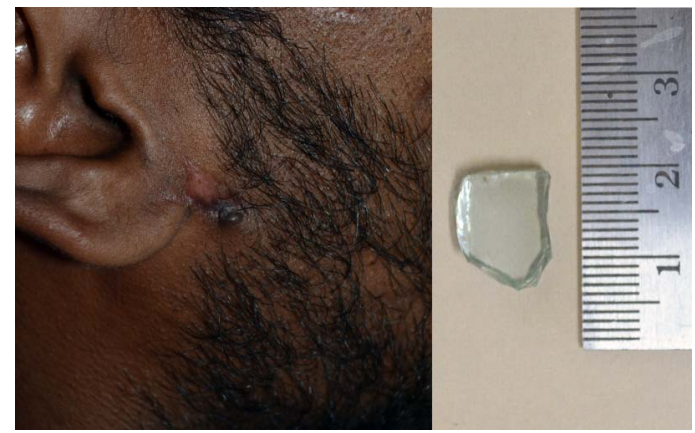

Figure 1 Laceration wound (left) and expulsed glass fragment (right).

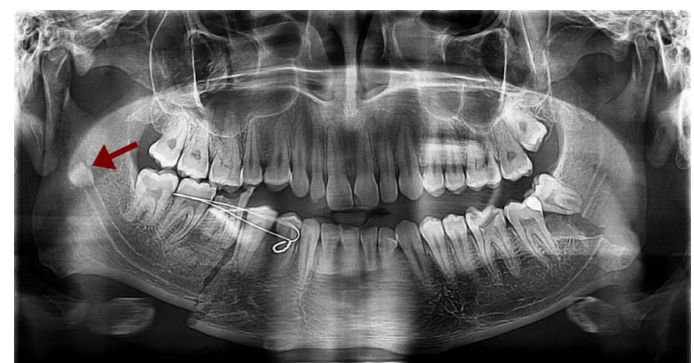

Figure 2 Dental panoramic radiograph showing embedded glass fragment.

First, most glass bodies are radio-opaque and detectable in a radiograph. ${ }^{1}$ Second, and more importantly, the need for careful assessment of all RTA-associated injuries for embedded foreign bodies cannot be overstressed. ${ }^{2}$

\section{Learning points}

- Most glass fragments are radio-opaque and are discernable even in plain radiographs.

- A vigilant search for embedded foreign bodies is mandatory in all cases of facial injuries resulting from road traffic accidents.

\section{Competing interests None declared.}

Patient consent Obtained.

Provenance and peer review Not commissioned; externally peer reviewed.

\section{REFERENCES}

1 Klein KA, Hobbs BB. Radio-opacity of glass: does the lead content matter? CMAJ 1995;153:1224.

2 Steele MT, Tran LV, Watson WA, et al. Retained glass foreign bodies in wounds: predictive value of wound characteristics, patient perception, and wound exploration. Am J Emerg Med 1998; 16:627-30

\footnotetext{
Copyright 2015 BMJ Publishing Group. All rights reserved. For permission to reuse any of this content visit http://group.bmi.com/group/rights-licensing/permissions.

BMJ Case Report Fellows may re-use this article for personal use and teaching without any further permission.

Become a Fellow of BMJ Case Reports today and you can:

- Submit as many cases as you like

- Enjoy fast sympathetic peer review and rapid publication of accepted articles

- Access all the published articles

- Re-use any of the published material for personal use and teaching without further permission

For information on Institutional Fellowships contact consortiasales@bmjgroup.com

Visit casereports.bmj.com for more articles like this and to become a Fellow
} 